\title{
新潟県の特産果樹の果実および廃棄部における機能性物質
}

\author{
児島清秀 ${ }^{1 *} \cdot$ 石橋卓馬 $^{1 \mathrm{a}}$ ・松本辰也 ${ }^{2} \cdot$ 安藤大悟 $^{3 b}$ \\ 1 新潟大学大学院自然科学研究科 950-2181 新潟市西区五十嵐二の町 \\ 2 新潟県農業総合研究所園芸研究センター 957-0111 新潟県北蒲原郡聖籠町真野 \\ 3 新潟大学農学部 950-2181 新潟市西区五十風二の町
}

\section{Functional Substances in Fruits and Waste Parts of Main Fruit Trees in Niigata Prefecture}

\author{
Kiyohide Kojima ${ }^{1 *}$, Takuma Ishibashi ${ }^{1 a}$, Tatsuya Matsumoto ${ }^{2}$ and Daigo Andou ${ }^{3 b}$ \\ ${ }^{1}$ Graduate School of Science and Technology, Niigata University, Ikarashi 2, Nishi-ku, Niigata 950-2181 \\ ${ }^{2}$ Niigata Agricultural Research Institute Horticultural Research Center, Mano, Seiro, Niigata 957-0111 \\ ${ }^{3}$ Faculty of Agriculture, Niigata University, Ikarashi 2, Nishi-ku, Niigata 950-2181
}

\begin{abstract}
Functional substances in young fruits (fruit thinning time) and picking fruits (including after ripening and removal of astringency) of 'Le Lechier', 'Hiratanenashi', 'Akatsuki', and 'Kosui' and pruned branches and deciduous leaves of 'Le Lechier' and 'Kosui' were analyzed. The polyphenol concentration was higher in the peel of all fruits in the picking fruits, but the concentration tended to decrease overall compared with the young fruits. In 'Le Lechier' and 'Kosui', the polyphenol concentrations were at the same level for the pruned branches and deciduous leaves. The concentrations of flavans were high in the peels of 'Le Lectier' and the peels and flesh of 'Hiratanenashi' in the young fruits. In the harvested fruits, the peel was higher in all varieties, in particular, the peels of 'Le Lectier' had a high concentration, showing the same tendency as the polyphenol concentration results. The radical scavenging ability was high in the flesh of young fruits. However, the picking fruits tended to decrease compared with the young fruits. The scavenging ability was also observed in the deciduous leaves of 'Le Lechier' and 'Kosui'. The presence of chlorogenic acid was detected in the peels and flesh of 'Le Lectier' and 'Kosui' in the young fruits, and in the peels and flesh of 'Le Lectier', 'Kosui', and 'Akatsuki' in the picking fruits.
\end{abstract}

Key Words : chlorogenic acid, flavans, 'Hiratanenashi', 'Le Lechier', polyphenol

キーワード：フラバン，“平核無’，クロロゲン酸，ポリフェノール，“ルレクチェ’

\begin{abstract}
緒言
‘ルレクチエ’は新潟県で主に生産されているセイヨ ウナシの品種で (児島, 2008, 2019), ‘平核無’ は新潟県に 原木があるカキの品種である(児島, 2004)。新潟県の園 芸（新潟県農林水産部農産園芸課，2019）によると, 2017 年の新潟県の収穫量は, カキ ( 平核無’がほぼすべて) が 10,300 トン, 二ホンナシ（“幸水”が主要品種）が 8,970 トン, セイヨウナシ（“ルレクチエ’が臣湆ずて）が 2,240トン，モモ（“あかつき’が主要品種）が2,210トン である. 地域特産果樹（試料として用いた果樹）の幼果や
\end{abstract}

2019 年 5 月 22 日 受付. 2019 年 7 月 31 日 受理.

本研究の一部は, 新たな農林水産政策を推進する実用技術開発 事業「雪室活用の西洋ナシの追熟制御と日本ナシの長期貯蔵の 技術開発（課題番号 2026）」により実施し, 園芸学会平成 31 年 度春季大会に抢いて発表した。

* Corresponding author. E-mail: kojimaki@agr.niigata-u.ac.jp

a 現在 : 陽進堂生産部門品質検査部

$\mathrm{b}$ 現在 : 京都大学大学院農学研究科
せん定枝・落葉などの廃棄する部位に有用な機能性物質の 存在を明らかにできれば，健康食品などに有効活用できる 可能性があるが，研究報告は少ない。

活性酸素（ラジカル）は，不対電子をもつ原子，分子や イオンを指す（近藤，1999）。活性酸素は通常，反応性が 高いために，生成するとすぐに他の原子や分子との間で酸 化還元反応を起こし，安定な分子やイオンとなる．この反 応によって，体内は酸化され，それが病気や老化の原因に なる。

植物からは抗酸化作用によって活性酸素を除去する様々 な成分が報告されている，ポリフェノールは，ベンゼン環 に複数の水酸基が結合したすべての化合物を指す。ポリ フェノールは5000種以上にも及び，果物には食物繊維に 次いで多く含まれている（須田ら，2005）。近年，ポリフェ ノールの抗酸化作用が注目され，生活習慣病の予防に効果 的な成分であることが明らかになってきた（中村，2001）.

フラボノイドはフラバン骨格を持つ誘導体で，活性酸素 の消去作用をもち，利尿，抗毛細血管透過，血圧降下作用 など様々な効果がある（杉浦，1998）。 
クロロゲン酸類は，一般的に植物界に広く存在するポリ フェノールであり, 桂皮酸誘導体とキナ酸のエステル化合 物の総称であり, 近年, クロロゲン酸類の生理活性とし て, 血糖值上昇抑制作用, 血圧改善作用, 抗発癌作用, 抗 酸化作用などが多数報告されており，その機能性が着目さ れている(紙谷ら，2009）.

アボカドやマンゴーなどの果皮には強い抗酸化作用を持 つといら報告（Matsusaka・Kawabata, 2010）や，ビワの幼 果に含まれる全フェノール濃度は非常に高いといら報告 （Dingら，1998）があるが, 果皮や幼果に関する研究は少 ない。 セイヨウナシ（石川，2000）ではポリフェノールと クロロゲン酸, モモ（Macheixら，1990）と“ルレクチ エ’（歌代・山田，1996）ではポリフェノール（歌代・山田, 1996), カキの葉ではポリフェノール（鶴永ら, 2006）の分 析が報告されている.

そこで本研究では, 果実や廃棄部の有用な成分量の解明 を目的として，“ルレクチエ’，“平核無”，“あかつき”， “幸水”などの幼果 (摘果期), 収穫果 (収穫適期) 扎よび ‘ル レクチエ’, “幸水”の世ん定枝・落葉中の機能性物質 を分析した。

\section{材料および方法}

\section{1. 供試材料}

\section{1）供試材料の入手}

セイヨウナシ“ルレクチエ’, ニホンナシ“幸水”, カ キ ‘平核無”およびモモ‘あかつき’の果実は新潟県農業 総合研究所園芸研究センタ一の試験場から入手した. 果実 はそれぞれの幼果（摘果期）扣よび収穫果（収穫適期）を 採取した (第 1 表). 収穫果の“ルレクチエ’は追熟後, ‘平核無” は脱渋処理後の果実を分析に使用した. 新潟県 で主要に栽培されており, 他県での分析の取り組みが見当 たらない‘ルレクチエ’と“幸水”に関しては, せん定 枝・落葉も採取した. 追熟後の ‘ラ・フランス’ は購入し た. ‘ルレクチェ’と“ラ・フランス’ は追熟後, 拈よび ‘平核無” は脱渋後の果実について分析したのは各処理の 完了後から出荷, 店頭販売までの廃棄果実を想定していた ためである。試料は分析まで $-30{ }^{\circ} \mathrm{C}$ で泠凍保存した。

\section{2）供試材料の調製}

果実は果皮と果肉に分け，5個以上の個体から均等に切 り出し, 果皮は $50 \mathrm{~g}$, 果肉は $100 \mathrm{~g}$, せ九定枝と落葉は $100 \mathrm{~g}$ を採取した。それらを，80\%エタノール中で磨砕し，ろ紙
(GF/B, 90 mm, Whatman, GEヘルスケア・ジャパン) で吸 引ろ過を行った，その後, 溶液を $80 \%$ エタノールで $200 \mathrm{~mL}$ に定容し，試料溶液とした。試料溶液をシリンジフィル ター $(0.22 \mu \mathrm{m})$ でろ過して, 以後にすべての分析に使用 した。

\section{2. 分析方法}

1) Folin-Denis 法（ポリフェノール）

ポリフェノールの測定は真部（2003）の方法を一部変更 した Folin-Denis 法を使用した。蒸留水 $(70 \mathrm{~mL})$ にタング ステン酸ナトリウム・2 水和物 $(10 \mathrm{~g})$, リンモリブデン酸 $(2 \mathrm{~g})$, 抢よびリン酸 $(5 \mathrm{~mL})$ を加光, 湯せん上で溶解し た. 冷却後, $100 \mathrm{~mL}$ に定容し, Folin-Denis 試薬とした.

蒸留水 $(3.2 \mathrm{~mL})$ を入れた試験管に試料溶液 $(200 \mu \mathrm{L})$, Folin-Denis 試薬 $(200 \mu \mathrm{L})$ を加光攪拌後に, 飽和炭酸ナト リウム水溶液 $(400 \mu \mathrm{L})$ を加光, 30 分間暗所で保存した. 分光光度計 (UV-1800, （株）島津製作所）で $700 \mathrm{~nm}$ の吸光 度をブランクとして，蒸留水を加えて，同様に吸光度を測 定した. ポリフェノール濃度は $(+)$-カテキン当量に換算 して示した.

\section{2) バニリン塩酸法（フラバン類）}

フラバン類の測定は谷口ら（2007）の方法を一部変更し たバニリン塩酸法を使用した．エタノール $(100 \mathrm{~mL})$ にバ ニリン（4g）を溶かしてバニリンエタノール溶液として使 用した. 試料溶液 $(200 \mu \mathrm{L})$ を遮光試験管に入れ，バニ リンエタノール溶液 $(1.2 \mathrm{~mL})$, 濃塩酸 $(600 \mu \mathrm{L})$ を加え, 攪拌後, 15 分間放置した. 分光光度計で $500 \mathrm{~nm}$ の吸光度 を測定し，ブランクには脱塩水を用いた。 フラバン類濃度 は (+)-カテキン当量に換算して示した.

\section{3） DPPH ラジカル消去法}

ラジカル消去能の測定は，高山ら（2010）の方法を一部 変更した2,2- ジフェニル-1-ピクリルヒドラジル $(\mathrm{DPPH})$ ラジカル消去法を使用した. $200 \mu \mathrm{M}$ に調整した DPPH エ タノール溶液 $0.3 \mathrm{~mL}, 100 \%$ エタノール $2.4 \mathrm{~mL}$ 打よび試料 溶液 $0.3 \mathrm{~mL}$ を混合し，30 分間暗所にて反応させた。 その 後, $517 \mathrm{~nm}$ の波長に設定した分光光度計で反応液の吸光 度 $\left(\mathrm{A}_{\mathrm{S}}\right)$ を測定した。試料溶液の代わりに同容の $100 \%$ 工 タノールを添加した場合の吸光度 $\left(\mathrm{A}_{\mathrm{C}}\right)$ をコントロール, $200 \mu \mathrm{M}$ DPPH エタノール溶液の代わりに $100 \%$ エタノール を添加した場合の吸光度 $\left(\mathrm{A}_{\mathrm{SB}}\right)$ を試料ブランクとして, 各 試料のラジカル消去率を以下の式で求めた.

$$
\text { 消去率 }(\%)=\left\{1-\left(\mathrm{A}_{\mathrm{S}}-\mathrm{A}_{\mathrm{SB}}\right) \cdot \mathrm{A}_{\mathrm{C}}{ }^{-1}\right\} \times 100
$$

第1表 幼果と収穫果の果実重

\begin{tabular}{|c|c|c|c|c|}
\hline & ‘ル レクチエ’ & ‘幸水’ & ‘平核無’ & “あかつき’ \\
\hline & \multicolumn{4}{|c|}{1 果実当たりの重さ $(g)^{z}$} \\
\hline 幼果（摘果期） & $9 \pm 1$ & $12 \pm 1$ & $24 \pm 1$ & $15 \pm 1$ \\
\hline 収穫果（収穫適期） & $363 \pm 13$ & $440 \pm 24$ & $216 \pm 6$ & $278 \pm 8$ \\
\hline
\end{tabular}

\footnotetext{
${ }^{\mathrm{z}} \mathrm{gFW} \pm$ 標準誤差 $(\mathrm{n}=10)$
} 
標準物質のトロロックスで検量線を作成し, ラジカル消 去能はトロロックス $(\mu \mathrm{mol} /$ 新鮮重 $)$ 量に換算して示した.

\section{4）クロロゲン酸}

LC/MS（LCMS-2010EV，（株）島津製作所）条件は次の と拈りであった：分析カラム； Inertsil ODS-3（粒径 $3 \mu \mathrm{m}$, 内径 $1.5 \times 150 \mathrm{~mm}, \mathrm{GL}$ サイエンス)：カラム温度 $; 35^{\circ} \mathrm{C}$, 流量 ; $0.15 \mathrm{~mL} ・$ 分 $^{-1}$, 移動相 ; エタノール $100 \%$.

HPLC（LC-20AP，（株）島津製作所）条件は次のと拈り であった：分析カラム; Inertsil ODS-3（粒径 $3 \mu \mathrm{m}$, 内径 $2.1 \times 250 \mathrm{~mm}, \mathrm{GL}$ サイエンス), カラム温度 ; $33^{\circ} \mathrm{C}$, 流量 ; $0.1 \mathrm{~mL} /$ 分，移動相; $0.1 \%$ 酢酸添加の超純水拈よび $0.1 \%$ 酢酸添加の $100 \%$ エタノールを使用したイソクラティック 溶離（超純水 $/$ エタール $=30 / 70$ ), 測定波長 ; $325 \mathrm{~nm}$.

\section{結果および考察}

1. ポリフェノール

\section{1）果実のポリフェノール}

ポリフェノールは, 幼果 (摘果期) では, ‘レクチ エ’の果皮と ‘平核無” の果肉が高い濃度であった（第 1 図 A). 収穫果 (収穫適期) では, 幼果と比較すると全体 的に濃度は低下寸る傾向にあった（第1図B）. リンゴで も同様に，完熟果実は未熟果実の約 $25 \%$ のポリフェノー ル化合物しか含んでいなかった（東ら，2013）。

すべての収穫果で，果皮の方が濃度が高かった。二ホン ナシで，ポリフェノール合成が停止して果実が肥大した ことでポリフェノール濃度が低下した（菅原・五十嵐, 2013)。ポリフェノールは苦味や渋味を呈する物質である ので（間苧谷・田中，2005），果実の成熟の進行に伴い，

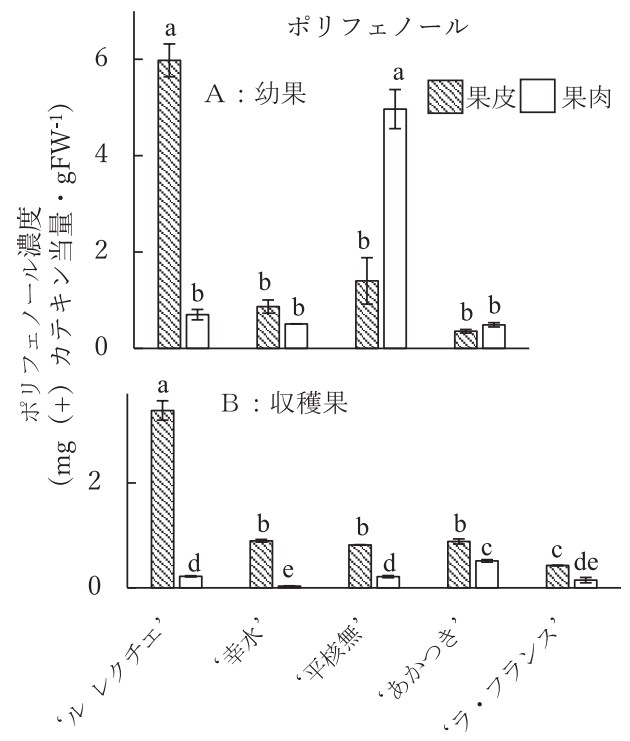

第 1 図幼果 (摘果期) ・収穫果の果皮・果肉のポリフェノー 儿濃度

図中の縦線は標準誤差を示す $(n=3)$ 図中の異なる英文字間は Tukey-Kramer 法の多重検定に より $5 \%$ 水準で有意差があることを示す
ポリフェノール濃度の低下により，渋味が抜けると考光ら れる。

“平核無” は不完全渋柿であり，幼果の果肉の高濃度の ポリフェノールは柿渋由来である（川口ら，2012；平， 2009)。収穫果の果肉ではポリフェノール濃度が減少して いたが (第1図)，これは脱渋によりタンニンが不溶化し たためと考えられる.

収穫果の果皮に関しては, ‘ルレクチエ’が‘ラ・フ ランス’に比べ約 8 倍高かった（第 1 図B)。“ルレクチ エ’は発育中を通じてポリフェノール合成を続けるため (歌代・山田，1996），収穫期のポリフェノール濃度が ‘ラ・フランス’より高いと考えられる.

2) せん定枝・落葉のポリフェノール

せん定枝では両品種で同程度の濃度であった（第 2 図）。 落葉に関しても品種間で同程度 $\left(3.6 \mathrm{mg} \cdot \mathrm{gFW}^{-1}\right)$ であっ た（第２図）。

\section{2. フラバン類}

\section{1）果実のフラバン類}

幼果では，“ルレクチエ’の果皮と“平核無”の果皮・ 果肉が高い濃度のフラバン類を含んでいた（第 3 図 A). 収穫果では，すべての品種で果皮の方がフラバン類濃度が 高かった（第 3 図B）、特に“ル レクチエ’の果皮が高い 濃度であった。

\section{2) せん定枝・落葉のフラバン類}

せん定枝では“ルレクチエ’が高い濃度のフラバン類 を含んでいた（第 4 図）。果実類では，フラバン類（第 3 図）とポリフェノールの濃度の結果（第1図）と一致する 傾向にあったが，せん定枝では異なっていた。“ルレク チェ’ ‘幸水’のせん定枝のポリフェノール濃度に大き な差はなかったが(第2図)，フラバン類では, ‘ レク チエ’の濃度 $\left(11.2 \mathrm{mg} ・ \mathrm{gFW}^{-1}\right)$ が “幸水’ の約 4 倍であっ た（第 4 図）。このことから，“ルレクチエ’と“幸水”て はポリフェノール成分の組成が異なっていることが示唆さ れた。落葉は品種間で同程度であり(第4 図)，ポリフェ ノール濃度の結果（第2図）と一致していた。

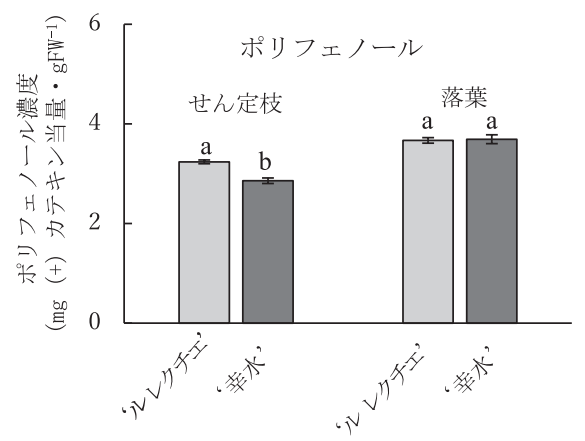

第 2 図 せん定枝・落葉のポリフェノール濃度 図中の縦線は標準䛊差を示す $(n=3)$ 図中の異なる英文字間は Tukey-Kramer 法の多重検定に より $5 \%$ 水準で有意差があることを示す 


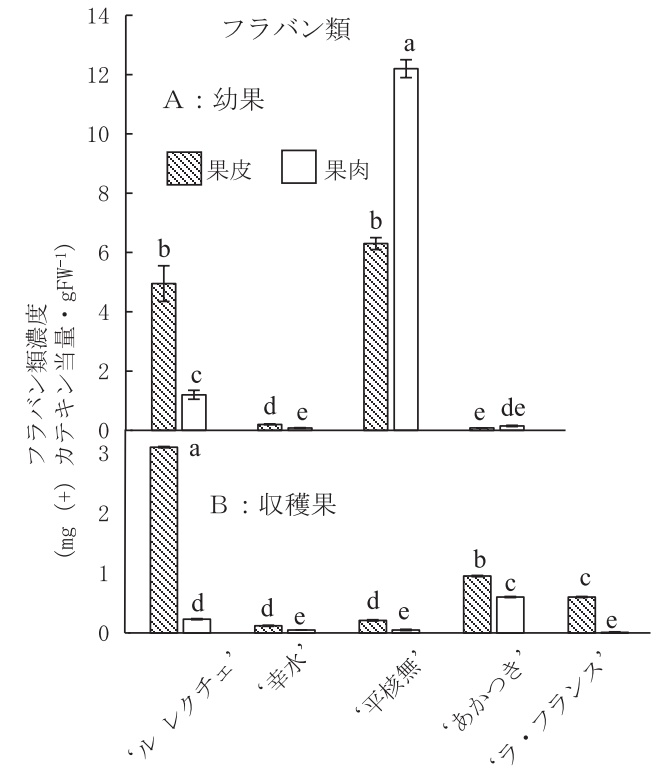

第3 図幼果・収穫果の果皮・果肉のフラバン類濃度 図中の縦線は標準誤差を示す $(n=3)$ 図中の異なる英文字間は Tukey-Kramer 法の多重検定に より $5 \%$ 水準で有意差があることを示す

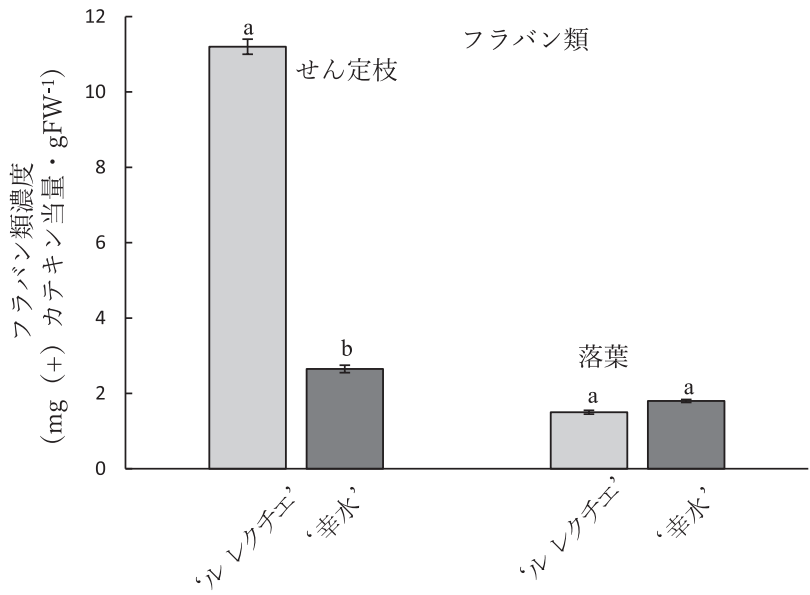

第 4 図 せん定枝・落葉のフラバン類濃度 図中の縦線は標準䛊差を示す $(n=3)$ 図中の異なる英文字間は Tukey-Kramer 法の多重検定に より $5 \%$ 水準で有意差があることを示す

\section{3. ポリフェノールとフラバン類の比較}

構造からポリフェノールはフラバン類を包含すると考党 られるが，Folin-Denis 法によるポリフェノールの值がバニ リン塩酸法によるフラバン類を包含することを示す報告は 見当たらない．

果実では概してポリフェノール濃度がフラバン類濃度と 比べて同等かそれ以上であった（第1図，第3図）。しか し，フラバン類濃度の方が特に高い材料は，“平核無”の果 皮・果肉である.

収穫果では，すべての品種で果皮の方がポリフェノール 濃度が高かった（第 1 図B）。特に‘ルレクチエ’の果皮

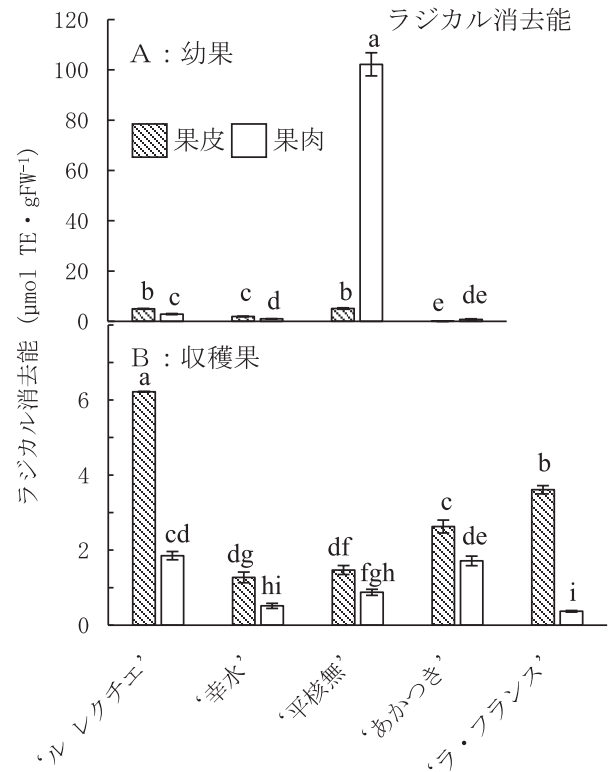

第 5 図幼果・収穫果の果皮・果肉のラジカル消去能 消去能はトロロックス当量 $\left(\mu \mathrm{mol} \mathrm{TE} ・ \mathrm{gFW}^{-1}\right)$ で表す 図中の縦線は標準䛊差を示す $(n=3)$

図中の異なる英文字間は Tukey-Kramer 法の多重検定に より $5 \%$ 水準で有意差があることを示す

が高い濃度であった。 これらの結果はフラバン類濃度の結 果（第3 図B）と同様であった.

“平核無”の幼果（第1図，第3図）と“ルレクチェ’ の剪定枝（第 2 図，第4図）のポリフェノール含量とフラ バン類を比較すると，両者ともフラバン類の方がかなり高 濃度である。そこで，フォーリンデニス法では呈色しない ポリフェノールで，バニリン塩酸法では呈色するフラバン 類が多く含まれている可能性がある.

\section{4. ラジカル消去能}

\section{1）果実のラジカル消去能}

健康食品などへの応用のために，抗酸化能の指標の一つ であるラジカル消去能を測定した。 ‘平核無”の幼果の果 肉に非常に高いラジカル消去能があった（第 5 図 A)，柿 渋の成分であるカキタンニンはプロアントシアニジンのポ リマー（縮合型タンニン）であり，プロアントシアニジ ンには非常に強い抗酸化能がある（細山・有賀, 1998). 従って，この非常に高いラジカル消去能はプロアントシア ニジン由来であると考えられる。

收穫果のラジカル消去能は幼果に比べ，低下している傾 向にあった。特に ‘平核無’の果肉では大きく低下してい た。収穫果の ‘平核無”の抗酸化能の低下の原因は，脱渋 によるカキタンニンの不溶化と推測される（石渡ら, 2003)。収穫果ではすべての果肉で，果皮に比べてラジカ ル消去能が低く(第 5 図 B), ポリフェノール濃度の結果 と一致していた。

‘ラ・フランス’ と比べて ‘ルレクチエ’の方が，果皮 では約 2 倍，果肉では約 10 倍，ラジカル消去能が高かっ 


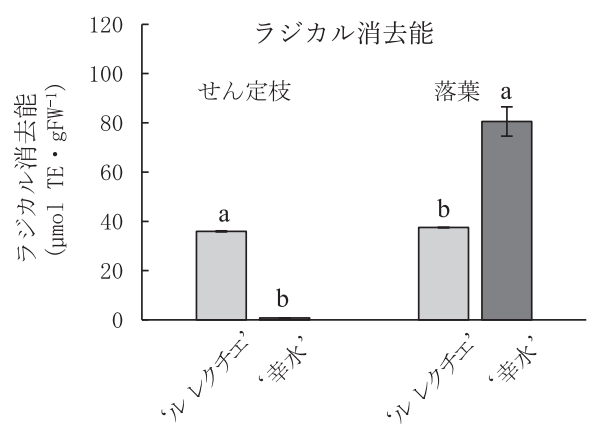

第 6 図せん定枝・落葉のラジカル消去能 図中の縦線は標準誤差を示す $(n=3)$ 図中の異なる英文字間は Tukey-Kramer 法の多重検定に より $5 \%$ 水準で有意差があることを示す

\section{た（第 5 図 B ）。}

\section{2）せん定枝・落葉のラジカル消去能}

“ル レクチエ’のせん定枝は“幸水”よりもラジカル消 去能が高かった (第6図). ‘ル レクチエ’と“幸水”の落 葉もラジカル消去能が認められた.

\section{5. クロロゲン酸}

\section{1）クロロゲン酸の定性}

第 7 図 A はクロロゲン酸の標品のマススペクトルで, 分 子イオン $(353 \mathrm{~m} / \mathrm{z})$ とベースピーク $(191 \mathrm{~m} / \mathrm{z})$ が確認でき た. 幼果の ‘ルレクチエ’の果皮（第７図 B）と“幸水” の果肉（第 7 図C）で分子イオンとベースピークが一致し て扣り，クロロゲン酸の存在が確認できた．幼果の“ル レクチエ’の果肉と“幸水”の果皮, 収穫果の“ルレク チエ’，“幸水”执よ゙゙あかつき”の果皮・果肉でもク口 ロゲン酸の存在が確認できた (データ略). セイヨウナシ とニホンナシの他の品種（石川, 2000）とモモの他の品種 （Macheix ら，1990）に扎いてもクロロゲン酸の存在の報告 があった。

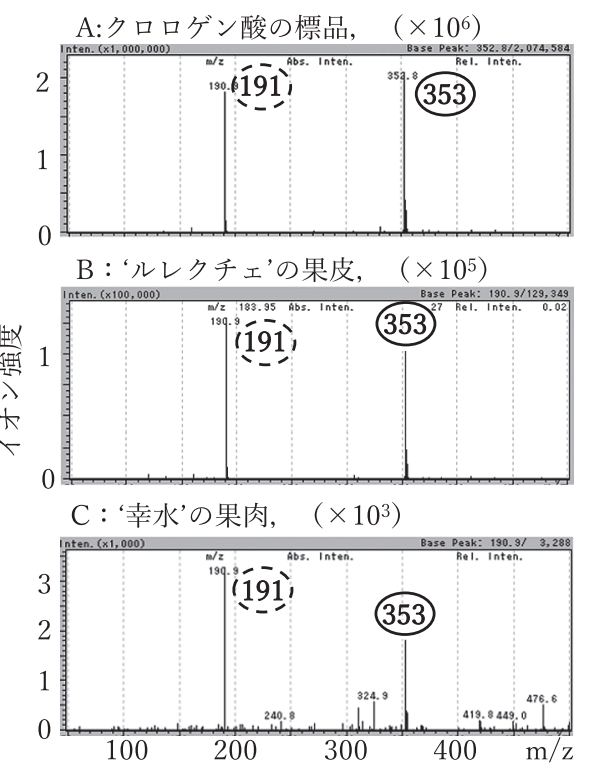

第 7 図幼果の果皮・果肉のクロロゲン酸のマススペクトル

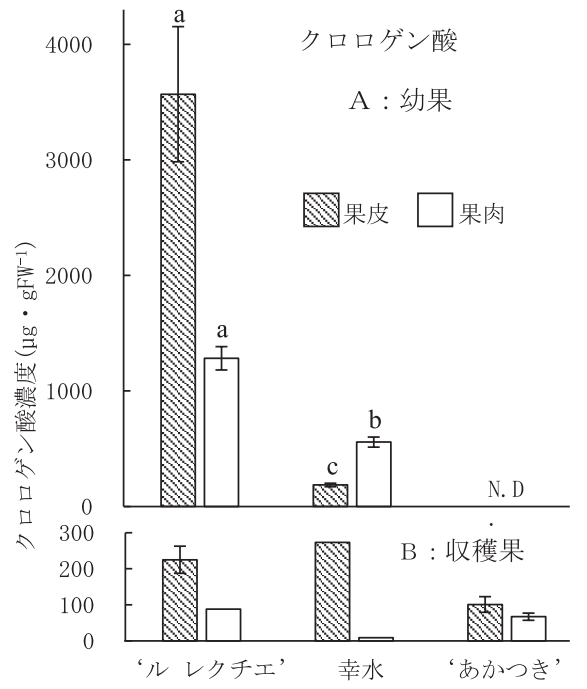

第 8 図幼果・収穫果の果皮・果肉のクロロゲン酸濃度 図中の縦線は標準誤差を示す $(\mathrm{n}=3)$

ただし，収穫果では“ルレクチエ’の果肉，“幸水” の果肉と果皮は 1 回の夕の定量である $(n=1)$

図中の異なる英文字間は Tukey-Kramer 法の多重検定に より $5 \%$ 水準で有意差があることを示す

収穫果では“ル レクチエ’の果皮と“あかりき’の果 肉と果皮間でTukey-Kramer 法の多重検定により $5 \%$ 水 準で有意差がなかった

\section{2）クロロゲン酸の定量}

幼果の“ル レクチエ’の果皮で高い濃度であった（第 8 図 A）。“幸水”も果皮と果肉でも定量できたが，“あから き’に颃いて，本報告の精製方法では夾雑物が除去できず 定量できなかった，收穫果では幼果と比べると濃度は低下 して扣り，3品種とも果皮の方が高い濃度であった（第 8 図B).

以上の結果より, 次の分析の部位が機能性食品の素材 (原料)として適している：1）ポリフェノールは“ルレ クチエ’の幼果と收穫果の果皮, “平核無” の幼果の果肉, “ルレクチエ’と“幸水”のせん定枝と落葉. 2) フラバ ン類も同様であり, 特に“ル レクチエ’のせん定枝.

\section{摘 要}

‘ルレクチエ’，“平核無”，“あかつき’，“幸水”などの 幼果 (摘果期), 収穫果 (追熟扮よび脱洪処理後を含も) 抒よび'ル レクチエ’，“幸水”のせん定枝・落葉中の機 能性物質を分析した。ポリフェノール濃度は, 収穫果に特 いて，すべての果実で果皮の方が高かったが，幼果と比較 すると全体的に濃度は低下寸る傾向にあった。“ルレク チエ’，“幸水’では，也ん定枝・落葉に関しても品種間で 同程度であった。フラバン類濃度は，幼果に打いて，“ル レクチエ’の果皮と“平核無”の果皮・果肉が高い濃度で あった，收穫果では，すべての品種で果皮の方が高かった が，特に“ル レクチエ’の果皮が高い濃度であった。こ れらの結果もポリフェノール濃度の結果と同じ傾向であっ 
た. ラジカル消去能は, ‘平核無”の幼果の果肉で高いレ ベルであったが, 収穫果では幼果に比べ, 低下する傾向に あった. ‘ルレクチエ’, ‘幸水” の落葉もラジカル消去 能が認められた. クロロゲン酸の存在が, 幼果に打いて “ルレクチエ’, “幸水”の果皮・果肉, 收穫果に扮いて “ルレクチエ’, “幸水”扎よび“あかつき’の果皮, 果肉 でも定性できた.

謝 辞 サンプル提供の御協力および御助言を頂いた新 潟県農業総合研究所園芸研究センタ一根津 潔氏抢よび榎 田暢美氏, 分析機器の操作にご協力を頂いた新潟県食品研 究所知野秀次博士に深く感謝致します.

\section{引用文献}

Ding, C., Chachin, K., Ueda, Y. and Mochioka, R. 1998. Changes in polyphenol concentrations and polyphenol oxidase activity of loquat (Eriobotrya japonica Lindl.) fruits in relation to browning. J. Japan. Soc. Hort. Sci. 67: 360-366. 東 知宏 - 長田恭一 - 相倉悦子 - 今坂 浩 - 半田正之 ・ 2013. りんご未熟果実由来ポリフェノール摂取による 肥満予防作用. 食科工誌. 60: 184-192.

細山 浩・有賀敏明. 1998. 10 プロアントシアニジン. p. 271-275. 谷村顕雄 (編) 植物資源の生理活性物質 ハンドブック。サイエンスフォーラム。東京.

石川祐子. 2000. 第2 章. III ナシの一般成分と機能性. p. 246-249. 津志田藤二郎編. 地域農産物の品質・機 能性成分総覧. サイエンスフォーラム。東京.

石渡仁子 - 高村仁知 ・ 的場輝佳. 2003. 干柿の製造過程に おけるラジカル捕捉活性の変化. 日本家政学会誌. 54: 449-456.

紙谷雄志・岩井和也・福永泰司・木村良太郎・中桐 理. 2009. 脱カフェインコーヒー豆抽出物の糖質分解酵素 阻害活性とクロロゲン酸類の寄与. 食科工誌. 56: 336-342.

川口 浩・武田美鶴・田中彩華・稲吉佳緒里・杉若侑治・ 香口智宏・高原百合子 - 村上誠悟 - 宗澤博文 - 水谷房 雄. 2012. 干し柿に打ける手揉みがカキのエタノール 生成と脱渋に及ぼす影響. 愛媛大農場報. 34: 11-16.

児島清秀. 2004. 果実のホルモン一神秘な植物ホルモンの 超微量な世界一. 新潟日報事業社.

児島清秀. 2008. 西洋ナシの「ル・レクチェ」一果実の成 熟生理と追熟一。農業抒よび園芸. 83: 1069-1073. 児島清秀. 2019. 西洋ナシの収穫後生理・技術; ‘ル・レ
クチェ’ [1]. 農業および園芸. 94: 509-513.

近藤和雄. 1999. 専門医がやさしく教える活性酸素. PHP 研究所. 東京.

Macheix, J.-J., A. Fleuriet and J. Billot. 1990. Fruit Phenolics. 1st ed. p. 17-126. CRC Press, Florida.

真部孝明. 2003. フローチャートで見る食品分析の実際 一植物性食品を中心に一. p. 79-88. 幸書房. 東京.

間苧谷 徹・田中敬一。2005.〈だもののはたらき。日園 連. 東京.

Matsusaka, Y. and J. Kawabata. 2010. Evaluation of antioxidant capacity of non-edible parts of some selected tropical fruits. Food Sci. Technol. Res. 16: 467-472.

中村 浩 (編著). 2001. 野菜の魅力. 化学工業日報社. 東京.

新潟県農林水産部農産園芸課. 2019. 新潟県の園芸. 新 潟.

須田郁夫 ・沖 智之・西場洋一 - 増田真美 - 小林美緒 - 永 井沙樹・比屋根理恵・宮重俊一。2005. 沖縄県産果実 類・野菜類のポリフェノール含量とラジカル消去活 性. 食科工誌. 52: 462-471.

菅原哲也・五十嵐喜治. 2013. 日本ナシ果実のポリフェ ノール拈よびラジカル消去活性の熟度による変化. 食 科工誌. 60: 516-520.

杉浦和彦. 1998. フラボノール類. 谷村顕雄 (編) 植物資 源の生理活性物質ハンドブック。 p. 105-108. サイ エンスフォーラム。東京.

平 智. 2009. カキ果実の脱淽機序の解明ならびに長期貯 蔵に関する研究. 日食保蔵誌. 35: 29-35.

高山侑樹・稲益和子・横山あゆ美・西田淑男・古市幸生. 2010. ニガイチゴ果実の一般成分，DPPH ラジカル消 去活性および血糖上昇抑制作用. 食科工誌. 57: 483488.

谷口抄子・黒田佳代 - 土居功一・稲田和敏・吉門直美 - 米 田裕治・田部昌弘・柴田高・吉田隆志・波多野 力. 2007 . 阿仙薬のポリフェノール性成分による品質 評価. 薬学雑誌. 127: 1291-1300.

鶴永陽子・松本敏一・倉橋孝夫・持田圭介・板村裕之. 2006. 収穫時期の違いがカキ ‘西条’の葉に打ける機 能性成分含量に及ぼす影響. 園学雑. 5: 321-324.

歌代景一・山田 寿. 1996. セイヨウナシ果実の発育中抒 よび追熟中に拈けるポリフェノール含量の品種間差異 と台木の影響. 園学雑. 64: 779-786. 